\title{
Copyright Infringement among Students of the Federal Polytechnic Ilaro and Federal College of Education, Osiele, Abeokuta
}

\author{
ODU Adejare Samuel, OBUN ANDY Maria Kisugu
}

\begin{abstract}
The focus of this research work was to carry out a survey of copyright infringement among students of the Federal Polytechnic Ilaro and Federal College of Education, Abeokuta. Research findings from previous empirical studies attested to the fact that copyright infringement was rampant but there were no enough survey on it. Moreover, thefocus of other studies was on universities with little or no attention given to the Polytechnics and Colleges of Education. Two research questions were raised to give direction to the study. The theoretical framework for this study was Knowledge Gap theory. Survey method was used for the study. A total number of $\mathbf{4 0 0}$ copies of questionnaire were administered and 392 copies were recovered and valid for the research. A stratified sampling technique was used. Findings show that the awareness of the provisions of copyright laws and plagiarism was not satisfactory. However, a higher knowledge of copyright infringement existed among the students of the Federal Polytechnic Ilaro than their counterparts in the Federal College of Education, Abeokuta. Furthermore, lack of research skills, pressure to meet deadlines for assignments and projects and laziness on the part of students were responsible for plagiarism among students. In view of the findings, it was recommended that the Federal Government through her agency (Federal Ministry Education) should develop strict rules for punishment on copyright infringement in its various forms and a need to employ plagiarism detention software in our schools.

Index Terms - Copyright Infringement, plagiarism.
\end{abstract}

\section{INTRODUCTION}

Highlight In any given society, laws are given as a means of regulating the activities and behaviors of individuals. To this end, the security of lives and property is ensured leading to peace and order. It is in such a situation that progress and development is experienced at all sides. One of such laws is the copyright Act that makes provision for the definition, protection, transfer, infringement and remedy, and penalty thereof of literary works, musical artistic works, cinematograph films, sound recordings, broadcast, and other ancillaries. Copyright aims at protecting the result of intellectual creativity and stimulates the creation of intellectual works of scholars.

According to Cornish (2004), cited by Aboyade, Aboyade and Ajala (2015 p.463), copyright springs from the fact that anything that is created is an extension of "self" and in that

ODU Adejare Samuel, Poly International College Ilaro, Ogun State, Nigeria.

OBUN ANDY Maria Kisugu, Department of Mass Communication, Federal Polytechnic, Ilaro, case it must be protected from general use by any one. That is, such creation should be protected from being used anyhow by any one for selfish gain. To him, copyright encourages the growth of writing, performing and creating of artistic works. In the absence of copyright there will be little or no incentive for people to create anything. Some people will use creations of other people to enrich themselves illegally.

Aboyade et al., (2015) note that students and teachers need vital information to excel in their academic pursuits. They need information to improve their social, economic and political experiences. By extension, education promotes both economic and technological development of any nation. Ideas and insights for achieving these are contained in the works of people which can be tapped to achieve that result. This is because a nation that is educated will develop and a nation that is developed will have opportunity to educate her citizens.

In Nigeria to be precise, there are many cases of copyright infringement that manifest in form of unauthorized reprography, plagiarism, and piracy. These have been causing headache for those in the academia, publishers, book sellers, and other stakeholders in the book industry. This is because book industry thrives majorly on copyright which is a protective arm of the law for creative people. It gives them certain exclusive rights to their works. In the absence of copyright, it may be difficult for publishers and authors to break even in business and still remain in such business because book publishing is about publishing good books at a profit. Ihebuzor(2013) submits in support of this assertion that, no matter how good the mission of a book publisher is, if he does not make profit, he will only last for a while before folding up.

Moreover, there are cases and reports of plagiarism among students of tertiary institutions in Nigeria. However, it is not new in the academia. There were documented cases of plagiarism in the scientific community of over 200 years (Hansen, 2002 cited in Bilic-Zulle ,Frkovic,Azman and Pretroveck, 2005). But it is fast becoming a worrisome issue with evidences from personal observations and from literatures available. Plagiarism is a plague that is ravaging our educational system at all levels and it is not peculiar to us in Nigeria alone but the world over. Onuoha and Ikonne(2013) in a study on the awareness and incidence of plagiarism among undergraduates in a Nigerian private university discovered that ( $82 \%$ ) of the respondents bought term papers from paper mill often, $(46 \%)$ admitted copying 
from a colleague's assignment without his knowledge or permission, while (4.7\%) admitted copying from colleague's assignment with his/her knowledge, (69.2\%) of the respondents admitted copying and pasting portions of text from the internet, $(65.7 \%)$ often copied verbatim from a textbook or journals without using a quotation mark, (58.5\%) often include references they did not use in their work and $(46.7 \%)$ often submitted assignments without references.Plagiarism is dangerous to academic health and ignoring this may be educationally counter-productive. This may allow students to continue to see it as a cheaper way to academic excellence. It is important to know that dishonest students may end up being dishonest in whatever chosen field they find themselves. Onuoha and Ikonne (2013) and Maina, Maina and Jauro (2014) stress that there are no enough survey of plagiarism in the Nigerian academia but there are reports of its rampancy in the system. To corroborate this, Orim, Davies, Borg and Glendinning (2013) find out in a research about some Nigerian postgraduate students in UK that they lack understanding and awareness of plagiarism from their previous universities in Nigeria. Orim, Borg and Awala-Ale(2013) revealed that in the developed countries, there has been much research into academic integrity with focus on plagiarism in the last ten years but little research is been done in the developing

\section{Statement of the Problem}

Copyright law is based on the assumption that authors of creative works are likely to be encouraged to embark on continuous production of intellectual products if there is a guarantee that they are not laboring for others to eat. Just as anybody wants to protect anything he possesses, creators of intellectual properties want to protect their works. Works belonging to other people should therefore be respected and not be used without permission if the work is copyrighted. In a nutshell, copyright governs the use of other people's work from illegal reproduction and distribution through photocopying and other means reproduction. Also, copyrighted materials are not allowed to be plagiarized. That is, proper attribution should be given to used sources and materials. An attempt in passing off of other author's ideas, words, or works as one's own is cheating that violates academic integrity. Copyright is contingent upon this fact that we are entitled to the fruits of our labour. It is the ownership of intellectual property with exclusive rights to our works. Inability to observe such on the use of other people's materials constitutes copyright infringement. However, the knowledge of what copyright is and what constitute copyright infringement is in doubt among undergraduate students in Nigeria. Research findings from previous empirical studies attested to the fact that awareness, perception, and reasons for photocopy of copyrighted materials are essential for the maintenance of academic repute. Onuoha and Ikonne (2013) and Maina, Maina and Jauro (2014) stress that there is no enough survey of plagiarism in the Nigerian academia but there are reports of its rampancy in the system. Moreover, majority of the available studies on copyright infringement did focus on universities and no polytechnic or college of education was included. Hence, this study is motivated to fill a gap in investigation of copyright infringement among students of polytechnics and colleges of education in Nigeria. In view of this therefore, this study investigated copyright infringement through photocopying and plagiarism among students.

\section{OBJeCTIVES OF THE STUDY}

The general objective of this study is to determine the prevalence of copyright infringement through photocopy and plagiarism among students. More specifically, the objectives of the study are:

(a) To find out if students of the Federal Polytechnic, Ilaro and Federal College of Education, Abeokuta are aware of the existence of copyright laws and what constitutes plagiarism?

(b) To investigate if there is difference in the awareness of copyright law and plagiarism among students of Federal Polytechnic Ilaro and Federal College of Education, Abeokuta.

\section{Research Questions}

The following research questions were raised to guide this study.

1) Are the students of Federal Polytechnic and Federal College of Education aware of the existence of copyright laws and plagiarism?

2) What is the difference in the awareness of the existence of copyright laws and plagiarism among the students of Federal Polytechnic Ilaro and Federal College of Education Abeokuta?

\section{Empirical Review and Theoretical Framework}

The theoretical framework for this study is Knowledge Gap Theory.Theory maintains that as media output grows in a given society, so will be the knowledge gap between the privileged and under privilege social group. Awareness of copyright law by some students may be due to the fact that they are information rich while those with no information may be due to the fact they are information poor. By application, it means that the information poor students and underprivileged may have little or no access to information on copyright and what constitute infringement, they are less aware of issues around the world and they may not know how it affects them. While those privileged students may have more access to copyright laws and what constitute copyright infringement as it relates to plagiarism. The review of literature for this study is carried out under the following identified variables in the study:

\section{Review 1: Copyright Laws}

Evidences from previous research works show that the level of awareness of the majority of students is very low and some are not aware of Nigerian Copyright laws at all (Igbeneghu,2009 and Aboyade et al., 2015).In contrast to this finding Omoba and Omoba (2009) found out that users of information resources and undergraduate students have knowledge of copy right laws and they also agree to their conditions. This means that students who are part of the users of information resources such as textbooks, journal, and periodicals are aware of the existence of copyright on those materials. To support this finding, 
Isiakpona(2012; Owushi-Junior(2016) and Sambo,Ahutu; Aworo(2016) and Gado(2016) in their studies observed that their respondents are very much aware of copyright laws but it does not influence their photocopying practice and the doctrine of fair use in copyright laws. Other research findings in this direction, Apronti (n.d) discovers that above 50\% of librarians in Ghana are aware of copyright law but the compliance is very low. Equally, Sritharan, Eik, Ying andEe(n.d)in their findings, it revealed that there was a relatively high awareness among undergraduate learners of copyright infringement but their actual level of knowledge of the same is very low. The study replicates the observation of Vasudevan and Suchithra (2013) that most doctoral students in a research were aware of copyright laws and its importance. Hence, implication for a need to raise the level of awareness for copyright laws. The discrepancies in these studies may be due to differences in circumstances in terms of time, location and methods of the studies (Nwana, 2005).

\section{Review 2:Plagiarism}

Many research studies have shown that plagiarism as a form of copyright infringement is not peculiar to Nigeria alone but it is world over. Some studies observed that plagiarism is as a result of the advent of internet and information technology which makes it easy to commit and detect (Bilic-Zulle et al., 2005; Orim et al., 2013 and Maina et al., 2014). In their observation, Maina et al. (2014) submit that there were no enough reports of academic dishonesty in the northern Nigerian universities. This could have been true of the fact that there are no enough reports on plagiarism in the northern universities but not for the prevalence. It must have been an occurrence that has been overlooked or attention was not paid to it. Several articles have stressed the alarming rate of plagiarism among students in Nigeria simply because of ignorance about plagiarism. Evidences abound of lack of awareness of plagiarism and what constitutes it among students.

Findings from the analysis of awareness and perception of plagiarism among postgraduate students indicate that an average of awareness of plagiarism exists among postgraduate students in Nigerian universities (Idiegbeyan-Ose, Nkiko and Osinlu,2016). It does mean that many of the postgraduate students did not have prerequisite knowledge of writing skills from their undergraduate level. Postgraduate studies should be more of independent study (Orim et al.,2013). Similarly, an earlier study carried out by Orim , Borg and Awala-Ale(2013) revealed that in the developed countries, there has been much research into academic integrity with focus on plagiarism in the last ten years but little research is been done in the developing world especially Nigeria.

Still on Orim et al. (2013), result of an interview with some participants in a study on students' experience of institutional intervention on plagiarism: Nigerian case shows that the academic climate and culture of United Kingdom is different to that of Nigeria. Most of the Nigerian students in a particular university in U K who were there for master's degree were found out neither to know what plagiarism is nor were they concerned about it. It was obvious from the interview for the study that many of the Nigeria students did not possess the knowledge of standard referencing. One of the respondents referred to his experience as "progressive journey backward". The experience took him back to fundamentals of academic writing of what he supposed to have learnt in the early academic background (Orim et al.,2013). In another study by Vasudevan and Suchithra (2013), they confirmed that a good number of doctoral students are less aware about plagiarism.

\section{Methodology}

The research design adopted was survey. This was adopted as research design for this study because it allows for assessment of certain attributes properties and characteristics of a situation at one or more points in time. It is because a sample of the target population was observed in their natural state to collect information on variables of interest that have to do with copyrights infringement among students.The population of the study consisted of all the students in the Federal Polytechnic Ilaro (6 889 students) and students of the Federal College of

Education, Abeokuta. (4 516 students) making a total number of 11405 students in both schools. The sample of the study would consist of 400 students in the Federal Polytechnic Ilaro and Federal University of Agriculture, Abeokuta. The sample for the research was calculated by using Taro Yamane (Yamane, 1973) formula with 95\% confidence level. The population for the two schools is 22000 students .The calculation formula of Taro Yamane is presented as follows:

$$
n=\frac{N}{1+N(e)^{2}}
$$

Where:

$\mathrm{n}=$ sample size required

$\mathrm{N}=$ number of people in the population

$\mathrm{e}=$ allowed error $(\%)$

Substituting numbers in formula:

$$
\begin{aligned}
& n=\frac{11405}{1+11405(0.05)^{2}} \\
& n=399.9649307 \\
& n=400 \text { (Rounded up) }
\end{aligned}
$$

A stratified sampling technique was used to select participants from different departments and different levels in the two schools. This sample comprised of 185 students from different departments in the Federal College of Education and 215 students from different departments in the National Diploma Level and Higher National Diploma Level in the Federal Polytechnic.

\section{Data ANALYSIS ANd Discussion of Findings}

\section{Sample Profile}

A total number of 400 questionnaires were distributed. The sample size was 400 students. The distribution was as follows: 
Copyright Infringement among Students of the Federal Polytechnic Ilaro and Federal College of Education, Osiele, Abeokuta

\begin{tabular}{|l|c|c|}
\hline & $\begin{array}{c}\text { Number } \\
\text { Distributed }\end{array}$ & $\begin{array}{c}\text { Number } \\
\text { Retrieved }\end{array}$ \\
\hline FPI & 215 & 212 \\
\hline FCE & 185 & 180 \\
\hline TOTAL & $\mathbf{4 0 0}$ & $\mathbf{3 9 2}$ \\
\hline
\end{tabular}

Source: Field study, 2017

\section{Analysis of Research Questions}

\section{Research Question 1:}

Are the students of Federal Polytechnic and Federal College of Education aware of the existence of copyright laws and plagiarism?

Table 2. Awareness of copyright laws among students

\begin{tabular}{|c|c|c|}
\hline $\begin{array}{c}\text { Awareness } \\
\text { Level }\end{array}$ & Frequencie & $\begin{array}{c}\text { Percentage } \\
(\boldsymbol{\%})\end{array}$ \\
\hline Fully Aware & 160 & $41 \%$ \\
\hline $\begin{array}{c}\text { Partially } \\
\text { Aware }\end{array}$ & 158 & $39.5 \%$ \\
\hline Never Aware & 48 & $12.2 \%$ \\
\hline Uncertain & 26 & $7 \%$ \\
\hline
\end{tabular}

Source: Field study, 2017

Table 3

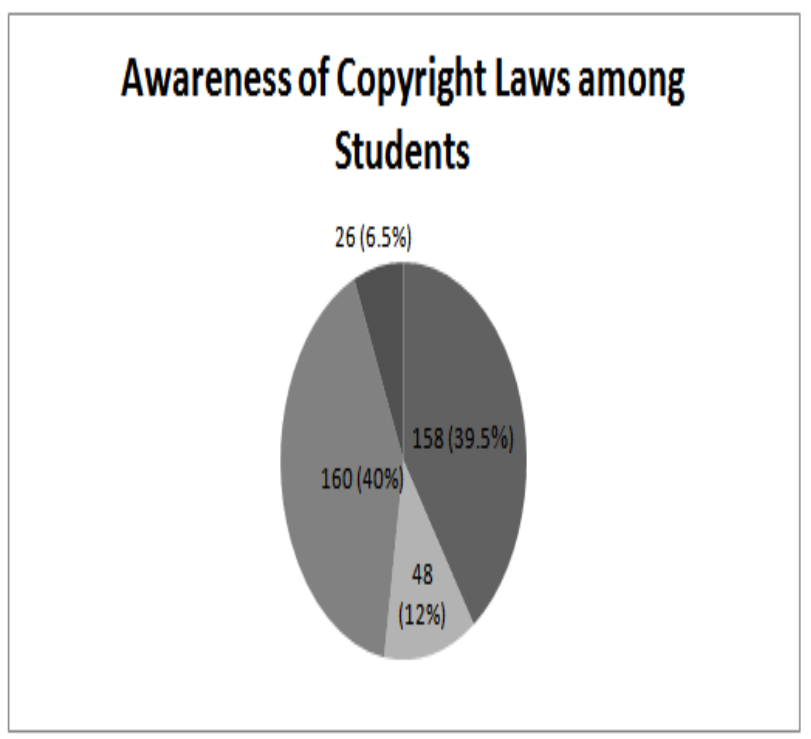

The result presented in the above chart clearly indicates that the students with full knowledge (40\%) and partial knowledge $(39.5 \%)$ of the existence of copyright laws are almost the same while few of them are not aware of the existence of copyright laws at all.

Table4 . Awareness of Plagiarism among Students

\begin{tabular}{|c|c|c|}
\hline $\begin{array}{c}\text { Awareness } \\
\text { Level }\end{array}$ & Frequencies & $\begin{array}{c}\text { Percentage } \\
(\boldsymbol{\%})\end{array}$ \\
\hline Fully Aware & 115 & $29.3 \%$ \\
\hline Partially Aware & 157 & $40.1 \%$ \\
\hline Never Aware & 90 & $23 \%$ \\
\hline Uncertain & 30 & $7.7 \%$ \\
\hline TOTAL & 392 & $100 \%$ \\
\hline
\end{tabular}

Source: Field study, 2017

Table 5

\section{Awareness of Plagiarism among Students}

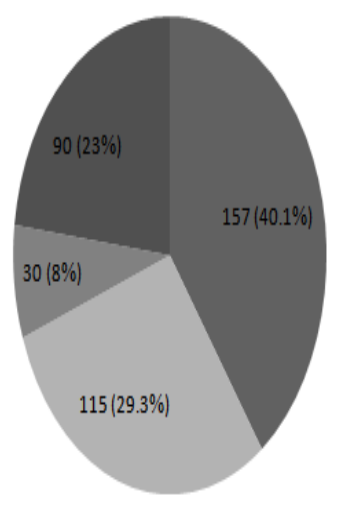

Source: Field study, 2017

This data suggests that more students have partial knowledge of plagiarism $(40.1 \%)$ and $(29 \%)$ claimed that they have full knowledge of what plagiarism is all about while $(23 \%)$ of the sample has no knowledge of what plagiarism is all about.

\section{Research Question 2}

What is the difference in the level of awareness of copyright laws and plagiarism between students of Federal Polytechnic and Federal College of Education?

Source: Field study, 2017

Table 6 . Level of difference in the awareness of copyright laws between FPI and FCE Students

\begin{tabular}{|c|c|c|c|c|c|c|c|c|c|}
\hline School & $\begin{array}{r}\text { Fully } \\
\text { Aware }\end{array}$ & $\%$ & $\begin{array}{l}\text { Partially } \\
\text { Aware }\end{array}$ & $\%$ & $\begin{array}{l}\text { Never } \\
\text { Aware }\end{array}$ & $\%$ & Uncertain & $\%$ & $\begin{array}{ll} & \text { Tota } \\
1 & \\
\end{array}$ \\
\hline FPI & 104 & $27 \%$ & 87 & $\%^{22.2}$ & 21 & $\%^{5.4}$ & - & & 212 \\
\hline FCE & 56 & $\%$ & 71 & $\%^{18.1}$ & 27 & $\%$ & 26 & $\%^{6.6}$ & 180 \\
\hline TOTAL & 160 & & 158 & & 48 & & 26 & & 392 \\
\hline
\end{tabular}

Source: Field study, 2017

This table shows that the level of awareness of copyright laws among students of the Federal Polytechnic is higher with (fully 
aware $27 \%$ ) and (partially aware (22\%) as against (fully aware 14.3\%) and (partially aware 18.1\%) in the Federal College of Education.

Table 7. Level of difference in the awareness plagiarism among students of FPI and FCE

\begin{tabular}{|c|c|c|c|c|c|c|c|c|c|}
\hline School & $\begin{array}{l}\text { Fully } \\
\text { Aware }\end{array}$ & $\%$ & Partially Aware & $\%$ & Never Aware & $\%$ & Uncertain & $\%$ & Total \\
\hline FPI & 77 & $\%^{20}$ & 96 & $\%^{25}$ & 39 & $\%^{10}$ & - & - & 212 \\
\hline FCE & 38 & $\%$ & 61 & $\%^{16}$ & 51 & $\%$ & 30 & $\%^{8}$ & 180 \\
\hline TOTAL & 115 & & 157 & & 90 & & 30 & & 392 \\
\hline
\end{tabular}

Source: Field study, 2017

The data presented here highlights the difference in the knowledge of plagiarism between students of FPI (full knowledge $20 \%$ and partial knowledge $25 \%$ ) while the statistics for FCE students show (full knowledge 9.6\% and partial knowledge 16\%). FCE recorded more students who are never aware and uncertain about the term plagiarism.

\section{DISCUSSION OF FINDINGS}

Research question one dealt with the awareness of existence of copyright laws and what constitutes plagiarism among students. The available data on the awareness of copyright laws among students suggests that the awareness level is a bit high in relation to few of the students who never have any knowledge of existence copyright laws. However, the students' knowledge of existence of copyright laws is not satisfactory simply because there is no clear distinction between students who claim full knowledge and partial knowledge of the existence of copyright laws. In some comparable studies, it was revealed that students were aware of the existence of copyright laws (Igbeneghu, 2009; Isiakpona, 2012; and Vasuderum and Suchithra,2013). In contrast, Aboyade et al, 2015 and Gado (2016) submit that the level of awareness of majority of students in their researches was very low and some are not aware of the existence of copyright laws at all.

On the knowledge of what constitutes plagiarism, the result of this study reveals that more students have partial knowledge of what constitutes plagiarism while a quarter of the sample for the study was not aware of what plagiarism is all about. This might suggest that Nigerian students have inadequate understanding of plagiarism. This result is similar to some studies carried out by different scholars on the awareness of plagiarism by Nigerian students both at undergraduate and postgraduate levels. It was found out that Nigerian students were deficient in their knowledge of plagiarism (Orim et al, 2013; Maina et al, 2014, Idiegbeyanwse et al, 2016 and Okere, et al. 2016). Knowledge gap theory explains and supports the findings of this survey. Awareness of the existence of copyright laws and what constitutes plagiarism may be due the fact that some students are information rich while others are information poor who have little or no access to needed information as regards copyright provisions and plagiarism.

Research question two gave attention to the difference in the level of awareness of copyright laws and plagiarism between students of Federal Polytechnic Ilaro and Federal College
Education Abeokuta. The data reveals that the level of awareness among students of the Federal Polytechnic is higher than that of students in the Federal College of Education. Also the awareness level of what constitute plagiarism among students of the Federal Polytechnic is higher than that of the students of the Federal College of Education. The findings here are evidences of low knowledge of the existence of copyright laws and plagiarism (Gado, 2016 and Okere, et al 2016). This could be taken as a limited evidence for the level of exposure between Polytechnic students and Colleges of Education students. Consequently, this finding emphasizes the knowledge gap theory. Colleges of Education students are less aware of issues around them and this may be due to their socio-economic background which may be poor.

\section{CONCLUSION AND RECOMMENDATIONS}

This study is an addition to the body of knowledge in the area of copyright infringement. Earlier studies have confirmed that there is no enough survey of plagiarism but there are reports of its rampancy in the system and mass photocopying of copyrighted books in the Nigerian academia are common place. Moreover, majority of the available studies on copyright infringement did focus on universities and no polytechnic or College of Education was included. In line with the results of this study, it is concluded that the awareness of provision of copyright laws is not satisfactory and the awareness of plagiarism is too low among students of Polytechnics and Colleges of Education in Nigeria.In line with the findings of this study the following recommendations were made:

1. The authorities of different educational institutions especially in polytechnics and colleges of education should as a matter of urgency step up machinery to create serious awareness among students about copyright laws, plagiarism and generally copyright infringement.

2. The Federal Government through her agency (Federal Ministry Education) should develop strict rules for punishment on copyright infringement in its various forms and a need to employ plagiarism detention software in our schools.

\section{REFERENCES}

[1] Aboyade, W.A. Aboyade, M.A. and Ajala, B.A. (2015). Copyright infringement and photocopy service among university students and teacher in Nigeria. International Journal of Art and Sciences. 
ISSN: $\quad$ 1944-693. $\quad$ Retrieved from

http://www.universitypublication.net>ijas > pdf on 06/09/2017

[2] Adedoyin, S.A, Ajala, B.A. and Aboyade, A.M. (2014).Book publishing - blending the old with new.Abeokuta: Eagle Publishers.

[3] Apronti, E. O.(2015). The awareness of the copyright law among library users in tertiary institutions in Ghana.Globus: Journal of Methodist University College Ghana(ISSN2026-5530) pp 30-48 Retrieved

fromhttps://www.africabib.org/query a.php?pe=!356295648!\&SR=3 on $06 / 09 / 2017$

[4] Bilic-Zulle, L, Frkovic, V, Azman,.T.T and Pretroveck (2005).Prevalence of plagiarism among medical students.Croat medical Journal. 2005; 46 (1): 126-131. Retrieved form http://www.cmj.jron 30 May 2017

[5] Gado, D. S (2016).Awareness and extent of infringement of copyright laws among undergraduate Students in Ahamadu Bello University Zaria, Kaduna State Nigeria.An Unpublished Masters Degree Project. Department of Library and Information Science Faculty of Education Ahamadu Bello University, Zaria, Nigeria.Retrieved from kubanni.abu.ed.ng >jspul>bitstream on 06/09/2017

[6] Idiegbeyan-ose, V, Nkiko, C and Osimuliu, I (2016). Awareness and Perception of plagiarism of post graduate students in selected Universities in Ogun State, Nigeria. Library Philosophy and Practice (e-jornal).Paper 1322. $\quad$ Retrieved from digitalcommonsunl.edu/libphi/prac/1322 on January 2017

[7] Ihubuzor, L.A. (2013). Book Publishing in Nigeria.Theories and Issues. Ibadan: College Press

[8] Igbeneghu, B. I. (2009). A survey of photocopying practices in some selected universities in Western Nigeria.Ozean Journal Social Sciences; 2(2) ISSN 1943-2577.

[9] Isiakpona, D.V. (2012). Undergraduate student's perception on copyright infringement: A case study of the University of Ibadan, Oyo State, Nigeria.Library philosophy and practice 2012, ISSN $1522-$ 0222.Retreived from http://www.webpages..vidatro...edu/.../isiakapona on 31 January 2016.

[10] Maina, B. A, Maina, B. M and Jauro, S.S (2014).Plagiarism: a perspective from a case of a northern Nigeria University.International Journal of Information Research and Review.Vol 1, issue, 12, pp. 225-230 December 2014. Retrieved from http://www.ijrr.com/sites/details//../0167.pdf on 29January 2017

[11] Nwana, O.(2005), Introduction to Educational Research. Ibadan: Hienman Educational Books (Nigeria) Plc

[12] Okere, S, Adam, E. M. and Sanusi, O. B. (2016). Awareness of plagiarism as copyright violation with implications for intellectual property education in tertiary institutions of learning. Journal of Research and Development Vol. 3, N.I, 2016.Arabian Group of Journals. Retrieved from http://www.arabianjbmr.com on 31March 2017

[13] Omoba, O. R. and Omoba, F. A. (2009).Copyright law: influence on the use of information resources in Nigeria; Library Philosophy and Practice. ISSN $1522 \quad-\quad 0222$. Retrieved from http://www.webpages.videho.edu/ mbolin/omoba.htm 23 April 2017

[14] Onuoha, D.U and Ikonne, C.N(2013). Dealing with the plague of plagiarism in Nigeria.Journal of Education and Practice. ISSN 2222-288X(online) Vol.4, No.11 2013. Retrieved from http:// www.iiste.org on 20 August 2017

[15] Orim, M, Borg. E and Awala- Ale., (2013). Students experience of institutional interventions on plagiarism: Nigerian case. In plagiarism across Europe and beyond.Conference proceedings June 12-13, 2103 Brno-(Zech Republic. $\quad$ Retrieved from http://plagiarism.pefkaimendelu.CZ/files/... on 23 February 2017

[16] Orim, M, Davies, W. J, Borg, E and Glendinning (2013).Exploring Nigerian postgraduate students experience of plagiarism. A phenomenographic case study. International Journal for Educational Integrity.Vol.9 No 1 June 2013 pp.20-341SSN 1833-2595. Retrieved from http://www.ojsunisa.edu.au/journals/index.php/WEI/ on 23 May 2017

[17] Owushi - Junior , E (2016). Librarians Awareness and application of the copyright law in academic libraries in Edo State of Nigeria. Retrieved from http://www.hdl.handle.net/123456789/2534 on 31 May 2017

[18] Vasudevan, T. M. and Suchithra, K.M (2013).Copyright awareness of doctoral students in Calicut University Campus.International Journal of Digital Library Services. Vol. 3 Oct - Dec 2013 Issue - 4 Retrieved from http://www.ijodls.inl.../vasuedantion-94-110-....on 21 April 2017

[19] Yamane, T. (1973) Chapter 3 Research Methodology. Retrieved from http://www.research.system.siam.edu/.../... on 27 January 2017 